\title{
An Analysis of the Current Situation and Future Development of College Counselors
}

\author{
Hongying Qiu \\ Guangdong University of Science \& Technology, Dongguan, China
}

Keywords: college counselors; team building; status quo; future development

\begin{abstract}
With the deepening of China's reform and opening up and the expansion of college enrollment, college counselors status and role is increasingly important. Counselors are an important part of college teachers, and the construction of college counselors is related to the development of education in our country.In recent years, the construction of college counselors has made great achievements, but there are also some problems that can not be ignored . Based on a comprehensive analysis of the status quo of the construction of counselors, this paper puts forward some effective countermeasures to further strengthen and improve the construction of the counselors.
\end{abstract}

\section{Career Orientation of University Counselors}

With the counselors are more and more things to do, the responsibility is more and more heavy, college counselors have become a college education can not be ignored groups, the following look at the different classes of college counselors career orientation.

The party and the government that college counselors to take the important task of cultivating students in the September 1, 2006 implementation of the Ministry of Education, "the provisions of the" clear the counselor has a dual identity of teachers and cadres, a full-time counselor can According to the teaching assistants, lecturers, associate professors, professors require the promotion of judges, requiring colleges and universities "should counselor team building and school teaching and research team construction is equally important position." The counselor's career has a clear positioning to enhance their social identity, in the system level can effectively stimulate the work of counselors passion.

There are many ways in which the academic profession can orientate counselors. Because counselors work content has been from the original ideological and political education for students to develop to the psychological counseling for students, employment guidance, interpersonal guidance and students to deal with daily things, so the counselor's career orientation has also emerged a lot of new words , "Counselors and intimate friends of college students' mental health", "teachers of moral education", "classes (buildings)," and "teachers and students", and the role of counselors as "the mentors of healthy growth of college students and the guide, the backbone of ideological and political education, Student affairs leaders, managers and service providers "and so on.

College leaders and colleagues have acknowledged the importance of counselors' work to students' healthy growth. However, the professional orientation of counselors has placed it in the teaching and research, and the students' ideological and political work has been subordinate. Some leaders and colleagues that all work with students can find counselors, counselors is actually college students nanny and attendant, is the campus firefighters, the requirements of the counselor to manage the incident is not the main event. With such a position, so counselors in the leadership and colleagues in the eyes of the status is significantly worse than teachers.

Counselor 's own professional orientation. Many counselors believe that their work is mainly class management, dealing with student affairs and provide students with a variety of services, they believe that their daily management of class and the affairs of the students are busy to do things, there is no more time for students Ideological and political education, students generally do not take the initiative to find a counselor to talk, unless he really has a problem.

In the minds of students, they believe that counselors are also focused on student affairs and 
provide some advice and services on their guidance and mental health counseling to do less, because college counselors and Students get along with less time, less understanding of the students, the impact of their life is not as good as often meet the professional teachers, what the general idea to find counselors help.

\section{Career Development of College Counselors}

With the college enrollment, the rapid and large contingent of counselors, counselors of varying quality, there is no professional, counselor entrance is low, the counselor's career planning, training, remuneration, evaluation of promotion there are many problems, leading to Counselors of their career development do not see hope, lost the enthusiasm of the work, so that college counselors have become short - term career.

Counselors training status is not optimistic. For a strong sense of responsibility and a sense of accomplishment counselors, their career development is more important than money, they are independent, like a challenging work, but also willing to work for it. Specific training in the table is below[Seventeen counselors randomly selected the number of times they took part in the training for more than one week since they served as counselors]:

\begin{tabular}{|c|c|c|}
\hline Project & Number of people & percentage(\%) \\
\hline 0 time & 7 & 41.18 \\
\hline 1 time & 8 & 47.06 \\
\hline 2times & 0 & 0 \\
\hline 3 times or more & 2 & 11.76 \\
\hline
\end{tabular}

Counselor's salary is lower than the average college teachers. Although the state explicitly affirms that college counselors have dual identities of teachers and cadres, in the actual school wage programs, the wages of counselors are generally lower than the full-time teachers of the school. The lack of scientific and effective way to assess the work performance of counselors. The complexity of the work of counselors, extensive, educational effects of lag and concealment, the infinite impact on students in the assessment can not give a good consideration given to the appropriate recognition, but generally give an "excellent, qualified "The conclusion, affecting the work of counselors enthusiasm.

Counselors career development space is narrow, the lack of professional, evaluation and promotion is difficult. Counselors in the specific work in general there is no professional division of labor, so that many counselors gradually lost their professional knowledge and professional skills. Although the school has provided counselors can switch to teaching posts and promoted to school administrators, but here the threshold is too high, too much competition, many counselors are far behind. Because there is no professional and technical positions in the evaluation of titles are often blocked. When they find that their promotion and transfer job in the foreseeable future, the value of work can not be sure, the loss of a sense of accomplishment and motivation of the instructors will be passive slow down, perfunctory, ready to give up counselors.

In short, to really let the counselors in the growth path of college students play an important role in guiding people and instructors, school leaders must pay attention to counselors career development status, analysis of reasons, change the concept of counselors to increase the construction of human and material resources, Financial investment, improve the counselor assessment and evaluation mechanism, broaden the counselors career development platform, stable counselor team.

With the improvement of socialist democracy and legal system and the perfection of socialist education system, the professional, professional and diversified development of the role of counselor is becoming more and more obvious. The colleges and universities for the counselor's own quality, the development of its own content also put forward higher requirements. And counselors in the professionalization, professionalism and diversification on the road only by their own in practice, constantly explore the study, continue to learn from and constant innovation to be able to adapt to changes in the social system, to adapt to the country for the promotion The Needs of 
College Instructors' Development and the Fundamental Goal of Promoting the All - round Development of College Students in the New.

\section{Future Development of University Counselor Team Construction}

\section{Specialization of Counselors}

Tan Chuanbao ever said that "modern education and ancient education, one of the most important difference is that education by the experience of Xingtai change Wei professional activities." From this sentence, we can see that the refinement of social division of teachers Professional and academic professional, and second, in the modern education, teachers must be in the field of scientific research and teaching has improved the third division of the school teaching and management to promote the role of the counselor in the new era to professional development the way.

In the sixty years of development, in the summary of counselors' development experience, we must develop the work of counselors as a professional discipline. If our counselor work is still only in the experience of exploration, there is no specific discipline as a support, then the team's role will be vague, can not be synchronized with other disciplines in colleges and universities, professional team Is without the source. In the modern, information technology and international education system, the counselors, whether as a management team or professional teaching team bear the brunt of their teachers or to play the role, rather than school-style "nanny" is not professional teachers to play the remaining work By. In the practice of college counselors' professional development in the new era, we should integrate scientific research, teaching and management, with particular attention to the development of the echelon of counselors. Making the team in the title structure in a breakthrough, and the formation of professional teachers consistent with the team building.

In the development of counselors in the process of specialization, counselors in the multiple identities of the premise, we should choose an important direction of development, selection of good team building leaders of the subject makes the team not only professional disciplines of knowledge support, But also with the ability of scientific research, not only to complete the task of management, but also in the teaching of a breakthrough and innovation. Counselors are the tutors, mentors and guides of college students, and they are also important forces of teachers in colleges and universities. Therefore, college counselors is necessary to become teachers and cadres of their duties, it is necessary to recognize their job responsibilities and professional development trends, to become a professional moral education until an expert.

\section{Professional counselors}

"The CPC Central Committee and State Council on further strengthening and improving the ideological and political education of the views" and in March 2015 two sessions on strengthening the construction of college counselor spirit, so that the new era of counselors can more clearly their own work tasks and Claim. The Ministry of Education in the "strengthening of college counselors on the construction of the views of the class teacher," clearly put forward the college counselor ranks of professional and professional development, take the "professional" development path is becoming an important college counselor team exploration and exploration Practical direction. With the reform and opening up is not strengthened, the internationalization of the deepening of social and economic development in the process of job requirements are also constantly professional. In recent years, China's education system reform, the great rejuvenation of the Chinese nation in the journey, our society needs more high-quality talent, so we also continue to strive for universal access to higher education, college entrance examination and college entrance examination reform A certain level so that the number of college students a sudden increase in the level of students is also increasingly complex. The living environment, learning environment and social employment of the university have undergone great changes. In the new era, with the unprecedented development of informationization and networking, the way students receive information has become diverse and complicated. In particular, Western hostile forces Through the network of information on China's various aspects of cultural penetration and changes in values, these shocks do not let us attach great importance, especially for this large group of colleges and universities, although the students mature 
but not stable enough, poor identification, not Able to distinguish between the cultural and ideological enemies. Therefore, these are the work of the counselor team responsibilities, work content and methods, training and training of the new and higher requirements. The professional construction of the counselor ranks is the inevitable requirement to adapt to the comprehensive development of college students.

\section{Diversification of counselors}

Under the modern management system, the counselors are an indispensable part of the school to implement the quality education, the modern education, the sustainable development of the school and the continuous delivery of talents for the society. From a single management position gradually transformed into a high level of teaching, business ability, scientific research ability and management experience of the prominent diversified talent. This is also the necessity of the development of the role of counselor in the new era. It is also an inevitable requirement for counselors to adapt to the development of the times, the development of higher education and the complexity of students.

\section{Reference}

[1] Hu Gang on the professionalization of the college counselors [J] Journal of the National School of Education, December 2008

[2] Wang Weiting. College counselors development trend of [J] Science and Technology Exchange (early version) in March 2008

[3] Tan Chuanbao.Specialization; strengthening the key to moral education effectiveness [J]. Counselor, 2006, (5): 30

[4]. Ren Yingming. College counselors professional development research [D] Shanxi University master's degree thesis 2010

[5] Yu Jun state university counselor role positioning and team building research [D] Xiamen University master thesis 2007 